\title{
Communication
}

[Comunicação]

\section{Spontaneous multi-cystic peripheral ameloblastoma in the freshwater angelfish, from the Brazilian state of Pará}

\author{
[Ameloblastoma periférico multicístico espontâneo em Acará Bandeira, \\ no Estado do Pará, Brasil]
}

\author{
M. Videira ${ }^{1}$, M. Velasco ${ }^{2}$, R. Tortelly ${ }^{3}$, S. C. São Clemente ${ }^{3}$, P. Matos ${ }^{4}$, \\ O. Sanches ${ }^{5}$ E. Matos ${ }^{2 *}$
}

\author{
${ }^{1}$ Universidade Estadual do Amapá - Macapá, AP \\ ${ }^{2}$ Universidade Federal Rural da Amazônia - Belém, PA \\ ${ }^{3}$ Universidade Federal Fluminense - Rio de Janeiro, RJ \\ ${ }^{4}$ Universidade Federal do Pará - Belém, PA \\ ${ }^{5}$ Universidade do Oeste Paulista - Presidente Prudente, SP
}

The systematic analysis of the health of aquatic organisms may provide an important indicator for the evaluation of the water quality of natural aquatic environments. Inadequate water quality may provoke a wide range of problems in aquatic organisms, including genetic mutations, infectious diseases, behavioral modifications, physical dysfunction (including reproduction) and deformations or dysplasia, neoplasia, and even death (Flores-Lopes and Malabarba, 2007).

The growing interest in fish tumors results from their potential as models for the understanding of equivalent alterations in humans, as observed in particular in the case of the zebrafish, Danio rerio (Feitsma and Cuppen, 2008; Marino et al., 2012). In addition, the occurrence of neoplasia in fishes may reflect the effects of aquatic pollution, and thus be used as indicators of the presence of carcinogenic agents in the environment, which may be potentially dangerous to humans (Sinderman, 1990).

A number of authors have recorded neoplasms in fish, in particular papillomas and melanomas (Ramos and Peleteiro, 2003). However, few data are available on the occurrence of odontogenic tumors (Vijayakumar et al., 2014) and in the tissue that forms the dental enamel, such as the

Recebido em 4 de junho de 2014

Aceito em 7 de abril de 2015

*Autor para correspondência (corresponding author)

E-mail: edilson.matos9@gmail.com ameloblastic cells, which are relatively rare in mammals and fishes (Gorlin, 1972).

Given this, the present study reports on the spontaneous occurrence of an ameloblastoma in a wild freshwater angelfish, Pterophyllum scalare, and provides a description of its histopathology and ultra-structure.

The tumor was obtained from a $P$. scalare specimen collected from its natural environment at the Belém Environmental Park, in the Brazilian state of Pará. Fish was kept in a freshwater aquarium. The tumoral mass was removed surgically and fixed in Davidson solution. The fish survived for another month, but following its death, it was fixed in $10 \%$ formalin.

The fixed tumor was sectioned, and the fragments dehydrated with an increasing ethanol series, diaphanized in xylol, and embedded in paraffin for analysis by light microscopy. Following microtomy, with a thickness of $4 \mu \mathrm{m}$, the sections were processed and stained with HE and Masson's trichrome.

For scanning electron microscopy (SEM), small fragments of the affected tissue were fixed in $3 \%$ glutaraldehyde buffered with sodium cacodylate (pH 7.2) for 12 hours at $4^{\circ} \mathrm{C}$, washed overnight in 
the same buffer and post-fixed in $\mathrm{OsO}_{4}$ buffered at $2 \%$ in the same solution for 3 hours at the same temperature. The samples were then dehydrated in an increasing ethanol series, dried to the critical point, and covered with a thin film of gold.

This study was approved by the Ethics Committee for Experiments with Animals/ Universidade Federal Rural da Amazônia (UFRA) (report number 013/2014).

The macroscopic examination revealed a mass of tumor tissue extending from the alveolar rim of the superior maxilla to the external surface of the lip (Fig. 1A). The tumor was whitish in color, translucent with opaque areas, multi-nodular, and firm in consistence, $10 \mathrm{~mm}$ in diameter, with a weight of $0.84 \mathrm{~g}$. The surface of the section was multi-cystic, pinkish in color, with dense vascularization, and diffusely-distributed spicules. Dental structures were embedded in this tumoral mass (Figure 1B).

Under SEM, the neoplasm was characterized by a number of spicules, which traversed the tumoral tissue in various directions, occupying a large part of the neoplasm and extending beyond it (Figure 1C). Microscopically, a neoplasic process was observed, which was made up of conjunctive tissue with myxoid characteristics, richly vascularized, in which fragments of osteoid tissue were observed. The analysis revealed a neoplasic proliferation of the odontogenic epithelium, in which the neoplasic cells were organized in the form of a palisade, with a number of overlapping layers.

It is interesting to note the epithelial structures in the form of nidi in the squamous epithelium, which were often transformed into cysts. These epithelial elements presented marked morphological variation in the coating of each cyst (Figure 1D). A thick, stratified, squamous epithelium enveloped the tumor, often in the form of cysts, which were projected into the myxoid tissue (Figure 1E).

The neoplasic epithelium overlaid the loose hyper-cellular conjunctive tissue with thin collagenous fibers, and was contiguous with the alveolar bone. The neoplasic cells were characterized by moderate anisocytosis and anisocariosis, vesicular chromatin, and a welldefined central nucleolus (Figure 1F). The diagnostic analysis of the formation of the tumor in the present study was based on macroscopic observations and histopathological examination combined with SEM.

In the microscopic analysis of ameloblastomas in chinook salmon, Oncorhynchus tshawytscha, Schlumberger and Katz (1956) observed that the tumor was characterized by an irregular mass of epithelial cells surrounded by conjunctive tissue, exactly as observed in the present study. Other studies have also confirmed the epithelial characteristics of odontogenic tumors, such as the peripheral palisades of the columnar epithelium and the basal layer between the epithelium and the stroma.

Ameloblastomas are rare in domestic animals, and there are no previous reports of their occurrence in fishes in Brazil (Ueki et al., 2004). In fact, there have been few reports of spontaneous cases anywhere in the World (Schlumberger and Katz, 1956; Grim et al., 2009).

Cytological and histopathological alterations of the tissue in fishes have been used as bioindicators of the effects of exposure to toxic substances, given that they reflect fundamental biochemical and/or physiological modifications of the organism. In particular, neoplasic lesions are commonly observed in bottom-feeding fishes from polluted areas, reflecting a clear association between these lesions and exposure to contaminants (Bernet et al., 1999).

High rates of occurrence in wild fish and the chemical induction of tumors in fishes in the laboratory have been well documented. However, little is known of the molecular origins of carcinogenesis in these animals. It is important to remember that, while there is a strong correlation between the occurrence of tumors and exposure to carcinogenic chemicals, it is extremely difficult to prove a causal relationship (Van Beneden et al,. 1990).

Keywords: fish, Pterophyllum scalare, histopathology, neoplasia 

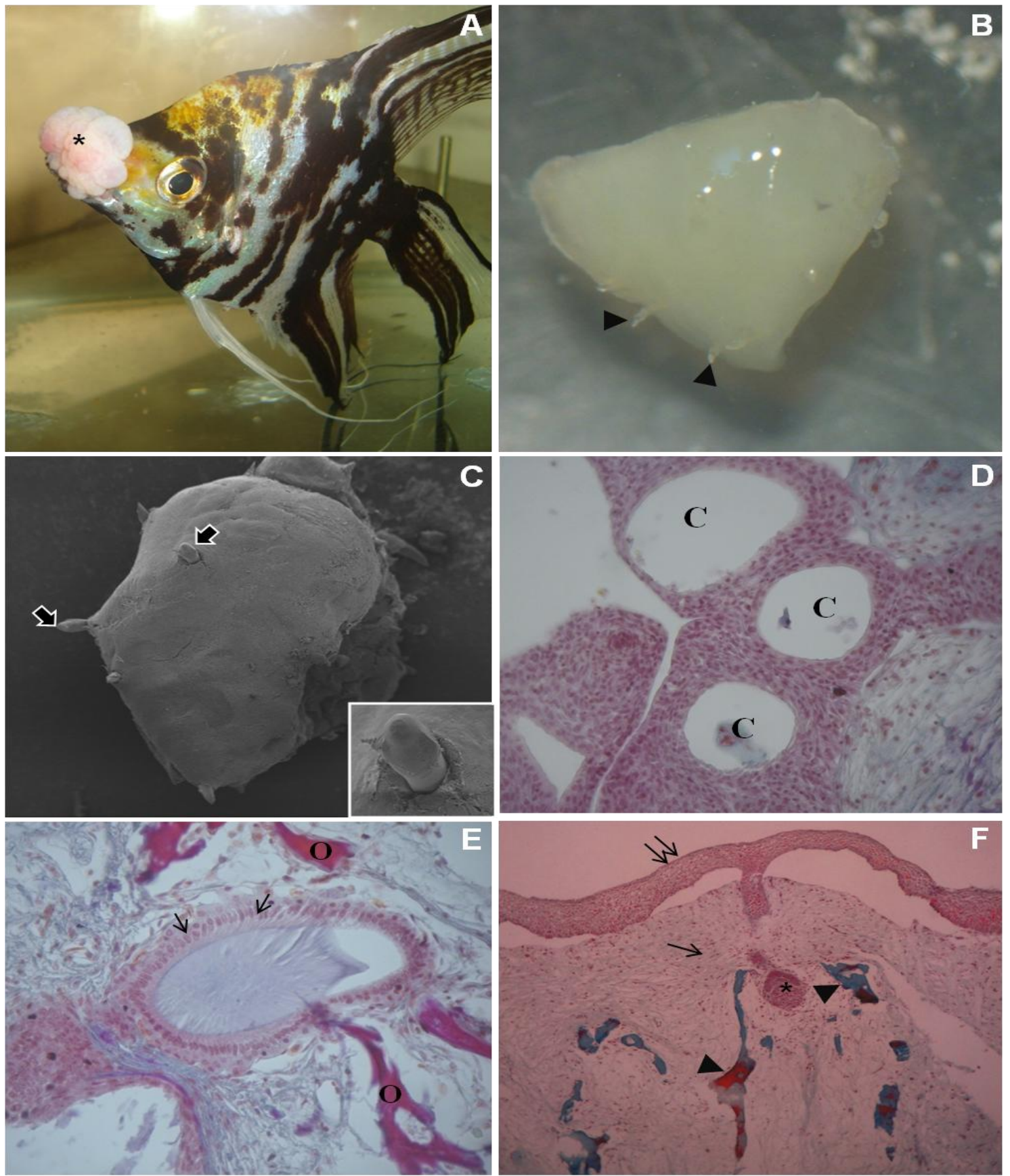

Figure 1. A. Freshwater angelfish. Multi-cystic peripheral ameloblastoma. Tumoral growth of the maxilla extending to the upper lip, approximately $10 \mathrm{~mm}$ in diameter $(*)$. B. Freshwater angelfish. Multi-cystic peripheral ameloblastoma. Fragment of the tumor, showing the teeth (arrowhead). Magnification: 1.25 x. C. Freshwater angelfish. Multi-cystic peripheral ameloblastoma. Spikules traversing the tumor (arrows), observad by SEM. D. Freshwater angelfish. Multi-cystic peripheral ameloblastoma. Multiple cysts embedded in the stratified squamous epithelium of the tumor lining (C). H.E. Magnification: 40 x. E. Freshwater angelfish. Multi-cystic peripheral ameloblastoma. Cyst lined with columnar epithelium in the form of a palisade with squamous layers (arrows) and osteoid tissue (O). H.E. Magnification: 40x. F. Freshwater angelfish. Multi-cystic peripheral ameloblastoma. Buccal epithelium (double arrows) with proliferation of the cells of the odontogenic epithelium forming layers of neoplasic cells (*) overlaying the loose hyper-cellular conjunctive tissue with thin collagenous fibers (arrow), contiguous with the alveolar bone (arrowhead). Masson's trichrome. Magnification: 20x. 


\section{RESUMO}

Este trabalho registra a ocorrência espontânea de ameloblastoma em P. scalare. O tumor foi obtido a partir de um exemplar de Acará Bandeira, sendo fixado, seccionado, e os fragmentos processados para microscopia de luz e microscopia eletrônica de varredura (MEV). O exame macroscópico evidenciou uma massa tumoral que se estendia do rebordo alveolar do maxilar superior à face externa labial. À MEV, a neoplasia apresentou uma série de espículas. Microscopicamente, percebia-se um processo neoplásico constituído por tecido conjuntivo de característica mixoide, ricamente vascularizado, onde eram observados fragmentos de tecido osteoide. A amostra revelou proliferação neoplásica do epitélio odontogênico, onde as células neoplásicas se organizavam na forma de paliçada. Alterações histopatológicas em peixes têm sido úteis biomarcadores do efeito à exposição a substâncias tóxicas, sendo as neoplasias lesões específicas, comumente encontradas em peixes de áreas poluídas, revelando uma associação entre as lesões e a exposição a irritantes.

Palavras-chave: peixe, Pterophyllum scalare, histopatologia, neoplasia

\section{ACKNOWLEDGMENTS}

We are grateful to the Brazilian agencies $\mathrm{CNPq}$ and CAPES for supporting this research, and to Dr. Claudio Lamarão (Electron Microscopy Laboratory, ICG-UFPA), and Dr. Hilton Tulio Costi at the Goeldi Museum (MPEG), for their help with electron microscopy.

\section{REFERENCES}

BERNET, D.H.; SCHMIDT, W.; MEIER, P. et al. Histopathology in fish: proposal for a protocol to assess aquatic pollution. J. Fish Dis., v.22, p.25-34, 1999.

FEITSMA, H.; CUPPEN, E. Zebrafish as a cancer model. Mol. Cancer Res., v.6, p.685-94, 2008.

FLORES-LOPES, F.; MALABARBA, L.R. Revisão de alguns aspectos da assembléia de peixes utilizados em programas de monitoramento ambiental. Vittalle, v.19, p.45-58, 2007.

GORLIN, R.J. Odontogenic tumors in mammals and fish. Oral Surg., v.33, p.86-90, 1972.

GRIM, K.C.; WOLFE, M.J.; EDWARDS, M. et al. Epizootic ameloblastomas in chinook salmon (Oncorhynchus tshawytscha) of the northwestern United States. Vet. Pathol., v.46, p.622-635, 2009.
MARINO, F.; LANTERI, G.; RAPISARDA, G. et al. Spontaneous schwannoma in zebrafish, Danio rerio (Hamilton). J. Fish Dis., v.35, p.239-242, 2012.

RAMOS, P.; PELETEIRO, M. C. Três casos de neoplasias espontâneas em peixes. Rev. Port. Ciênc. Vet., v.98, p.77-80, 2003.

SCHLUMBERGER, H.G.; KATZ, M. Odontogenic tumors of salmon (ameloblastic fibroma). Cancer Res., v.16, p.369-370, 1956.

SINDERMAN, C. J. Neoplastic diseases. In: SINDERMANN, C.J. Principal diseases of marine fish and shellfish. 2.ed. Waltham: Academic Press, 1990. p.173-199.

UEKI, H.; SUMI, A.; TAKAISHI, H. et al . Malignant ameloblastic fibro-odontoma in a dog. Vet. Pathol., v.41, p.183-185, 2004.

VAN BENEDEN, R.J.; HENDERSON, K.W.; BLAIR, D.G. et al. Oncogenes in hematopoietic and hepatic fish neoplasms. Cancer Res., v.50, p.5671-5674, 1990.

VIJAYAKUMAR, R.; GOPALAKRISHNAN, A.; RAJA, K. et al. Occurrence of tumour (odontoma) in marine fish Sphyraena jello from the southeast coast of India. Dis. Aquat. Org., v.108, p.53-60, 2014. 